OPEN ACCESS

Edited by:

Urs Feller,

University of Bern, Switzerland

Reviewed by:

Mariana Ornaghi,

State University of Maringá, Brazil

René Baumont,

INRAE Clermont-Auvergne-Rhône-

Alpes, France

*Correspondence:

Juan J. Villalba

juan.villalba@usu.edu

Specialty section:

This article was submitted to Agroecology and Ecosystem Services, a section of the journal

Frontiers in Sustainable Food Systems

Received: 27 May 2020 Accepted: 19 February 2021

Published: 19 March 2021

Citation:

Villalba JJ, Ates S and MacAdam JW (2021) Non-fiber Carbohydrates in

Forages and Their Influence on Beef Production Systems.

Front. Sustain. Food Syst. 5:566338.

doi: 10.3389/fsufs.2021.566338

\section{Non-fiber Carbohydrates in Forages and Their Influence on Beef Production Systems}

\author{
Juan J. Villalba ${ }^{1 *}$, Serkan Ates $^{2}$ and Jennifer W. MacAdam ${ }^{3}$ \\ ${ }^{1}$ Department of Wildland Resources, Utah State University, Logan, UT, United States, ${ }^{2}$ Department of Animal and Rangeland \\ Sciences, Oregon State University, Corvallis, OR, United States, ${ }^{3}$ Department of Plants, Soils and Climate, Utah State \\ University, Logan, UT, United States
}

Forages can provide a complete diet for ruminant animals, increasing the sustainability of beef production systems worldwide while reducing competition with humans for agricultural land or grain crops. Much of the emphasis on the nutritional characteristics of forages has been on the fiber, sugars, starch, and protein they supply to the rumen, despite the fact that other less-explored constituents, i.e., neutral detergent soluble fiber (NDSF) and other non-structural or non-fiber carbohydrates (NFC) also play a key role in the nutrition of ruminants. This paper explores the less investigated potential of temperate legumes to accumulate levels of NFC comparable to corn silage or beet pulp in cool, dry environments under irrigation, and its implications for forage-based beef production systems. We conclude that genetic or managerial interventions (i.e., breeding programs, defoliation frequency) or ecological conditions (i.e., climate, elevation) that increase concentrations of NFC in legumes can enhance beef production, meat quality, and the efficiency of nitrogen utilization by ruminants while reducing environmental impacts.

Keywords: neutral detergent soluble fiber, legumes, carbohydrates, beef production systems, cattle

\section{INTRODUCTION}

The most productive cultivated forages such as grasses, legumes, and forbs provide a complete diet for the ruminants-primarily cattle and sheep-with which they co-evolved (Grove and Rackham, 2001; Diamond, 2002). Most cultivated forages used in temperate climates originated in the Mediterranean regions of southern Europe and North Africa (Zeder and Hesse, 2000; Wilkinson et al., 2004). Unlike grain crops, the entire shoot biomass of forages is grazed or harvested and fed to ruminants as hay or silage. Plant tissues are composed of cell with walls of varying thicknesses composed primarily of cellulose (Gilbert, 2010; Cosgrove, 2012), which can be digested by rumen microbes (Allen and Mertens, 1988; Weimer, 1992). Forage biomass is often characterized by the relative proportions of fiber, which refers to the dry mass of plant cell walls, and cell contents, which refers to the dry mass of lipids, sugars, proteins, nucleic acids, and nutrient ions in the protoplasm of plant cells (Figure 1) (Van Soest, 1994).

When the nutritive value of grasses and legumes cultivated in temperate climates is compared, the concentraton of fiber is greater in grasses (e.g., $65 \%$ of dry mass) than in legumes (e.g., $50 \%$ of dry mass), while the concentration of protein is greater by a similar proportion in legumes, largely because the leaves of legumes are low in fiber and because legumes create sufficient nitrogen fertilizer for their own needs internally, in association with soil bacteria (Van Soest, 1994; Franche et al., 2009; Garg, 2009). Feed consumed by cattle is digested by microbes including bacteria, 


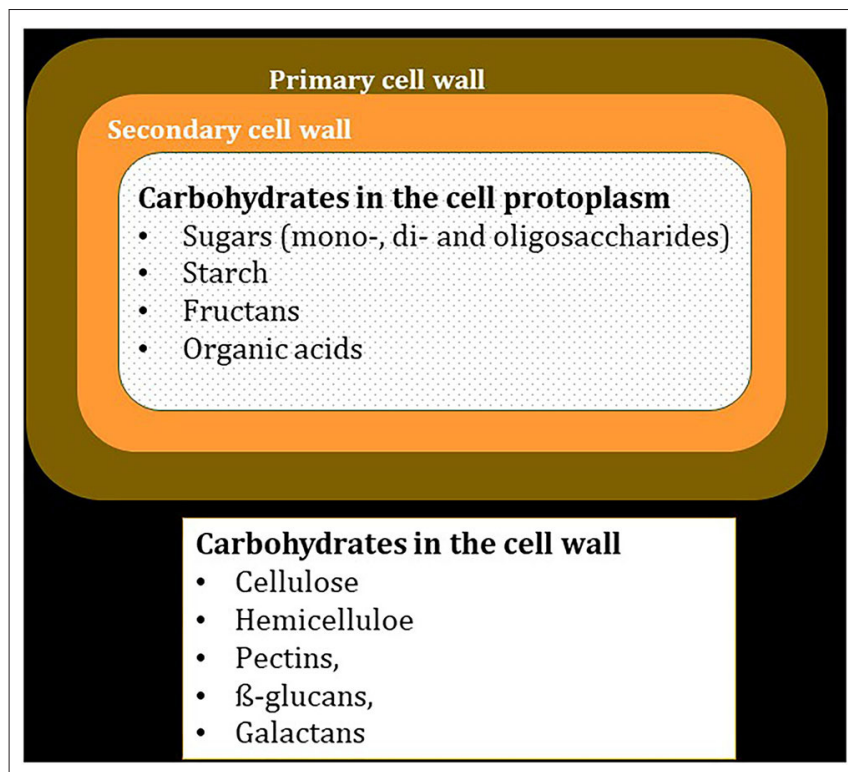

FIGURE 1 | A simple schematic to illustrate the carbohydrates located in plant cell walls or in the protoplasm, enclosed by the cell membrane.

archaea, protozoa, and fungi in a large forestomach, the reticulorumen. As is the case for other microbial systems, the balance of available proteins and carbohydrates in the rumen dictates the rate of microbial colonization of organic matter (Hall et al., 1999; Hall and Herejk, 2001). This is similar to soil microbial systems, where sufficient nitrogen must be present for microbes to mineralize roots or the plant litter that accumulates on the soil surface (Rigby et al., 2016), and it is also important in the rumen, where forage biomass is digested by microbes that are in turn digested by the ruminant (Nocek, 1988; Archimède et al., 1997; Owens et al., 2014). This paper focuses on the importance of the nutritive value of grasses and legumes for beef production systems, with emphasis on the less investigated potential of temperate legumes to accumulate significant levels of readily digestible carbohydrates in their shoots when grown under irrigation in semi-arid temperate climates.

\section{PLANT CARBOHYDRATES}

The structural or cell wall fraction of forages is a biologically complex entity representing the incompletely digestible fraction of forages, comprising the carbohydrates cellulose, hemicellulose, pectic substances, galactans, and ß-glucans (Table 1), plus the phenolic macromolecule lignin. The hemicellulose-lignincellulose, or neutral detergent fiber fraction (NDF) of cell walls, is insoluble in neutral detergent solution, and the lignincellulose, or acid detergent fiber (ADF) fraction is insoluble in acid detergent solution, chemicals commonly used for in vitro analysis of forages (Van Soest, 1994). In contrast, the nonstructural or cell contents fraction of plant material comprises the carbohydrates starch, sugars (water soluble carbohydrates; WSC), organic acids (OA) and fructans (Table 1), plus lipids,
TABLE 1 | Structural (cell wall) and non-structural (cell contents) carbohydrate components of forages.

\begin{tabular}{|c|c|c|c|c|c|c|}
\hline \multicolumn{2}{|c|}{$\begin{array}{c}\text { Plant } \\
\text { carbohydrates }\end{array}$} & \multicolumn{3}{|c|}{$\begin{array}{l}\text { Analytical } \\
\text { fractions }\end{array}$} & \multirow{2}{*}{$\begin{array}{l}\text { Digestible by } \\
\text { mammalian } \\
\text { enzyme } \\
\text { No }\end{array}$} & \multirow{2}{*}{$\begin{array}{l}\text { Common sources } \\
\mathrm{C}_{3} \text { and } \mathrm{C}_{4} \text { grasses and } \\
\text { legumes }\end{array}$} \\
\hline \multirow{5}{*}{ 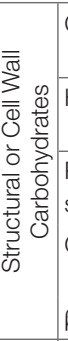 } & Cellulose & 晏 & 茨 & & & \\
\hline & Hemicellulose & & & & No & $\begin{array}{l}\mathrm{C}_{3} \text { and } \mathrm{C}_{4} \text { grasses and } \\
\text { legumes }\end{array}$ \\
\hline & $\begin{array}{l}\text { Pectic } \\
\text { substances }\end{array}$ & & \multirow{7}{*}{$\begin{array}{l}0 \\
\frac{1}{z}\end{array}$} & & No & $\begin{array}{l}\text { Legumes, forbs, citrus } \\
\text { pulp, sugar beet pulp }\end{array}$ \\
\hline & Galactans & $\begin{array}{l}\frac{u}{\infty} \\
\stackrel{0}{Z}\end{array}$ & & & Partially* & $\begin{array}{l}\text { Legumes, Lupinus } \\
\text { seeds }\end{array}$ \\
\hline & $\beta$-glucans & & & & No & Small grains \\
\hline \multirow{4}{*}{ 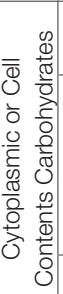 } & Fructans & & & \multirow{3}{*}{ 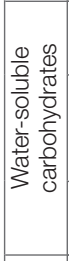 } & No & $\begin{array}{l}\text { Temperate cool season } \\
\text { grasses }\end{array}$ \\
\hline & Sugars & & & & Yes & $\begin{array}{l}\text { Corn, small grain } \\
\text { products, bakery } \\
\text { waste, potatoes }\end{array}$ \\
\hline & $\begin{array}{l}\text { Organic } \\
\text { acids }\end{array}$ & & & & Yes & $\begin{array}{l}\text { Molasses, sugar beet } \\
\text { pulp, citrus pulp }\end{array}$ \\
\hline & Starch & & & & Yes & Silage, additives, whey \\
\hline
\end{tabular}

*Mammalian enzymes partially digest some galactans (Hall et al., 1999).

$A D F$, acid detergent fiber; NDF, neutral detergent fiber; NDSF, neutral detergent soluble fiber; NFC, non-fiber carbohydrates. The NDSF fraction is solubilized when dried, milled plant material is boiled for $30 \mathrm{~min}$ in neutral detergent solution while the NDF fraction is not. Neutral and acid detergent solutions and analytical procedures for other plant carbohydrate components are described by Hall (2000).

proteins and nucleic acids, and is soluble in neutral detergent solution (Van Soest, 1994; Hall et al., 1999). Pectins, galactans and $B$ glucans are located in the cell wall and are considered structural carbohydrates but are soluble in neutral detergent solution and readily digestible by rumen microbes. They are therefore included in non-fiber carbohydrates (NFC) along with starch, WSC, OA, and fructans (Table 1). The components of the neutral detergent-soluble or NFC fraction of forages are the basis for another important nutritive value characteristic of feeds, total digestible nutrients (TDN), a metric that summarizes the energy value of ruminant feeds required for the production of milk and meat (Van Soest, 1994). High-quality forages grazed by cattle often have excessive protein but insufficient energy. When this occurs, amino acids are deaminated and used for energy, resulting in significant $\mathrm{N}$ losses to the environment (Satter and Roffler, 1975; Haynes and Williams, 1993). Therefore, identifying growth conditions that increase the energy value of forages and balance the ratio of energy to protein in forages will allow greater efficiencies and ruminant productivity while reducing the environmental impacts of livestock production systems without adding costly inputs.

\section{NON-FIBER CARBOHYDRATES AND RUMINANT NUTRITION}

The diverse group of carbohydrates accumulated in the shoots of forage plants are chemically and nutritionally complex (Hall et al., 1999). We will distinguish the readily digestible NFC carbohydrates from slowly digestible cellulose and hemicellulose, 
or NDF. Some authors refer to NFC by the more technical term neutral detergent-soluble carbohydrates (NDSC) (Hall et al., 1999). We will refer to the subset of NFC found in the cell wall (galactans, pectins and $ß$ glucans) as neutral detergent-soluble fiber or NDSF (Table 1) (Hall et al., 1999).

In grains, the NFC fraction is dominated by starch (e.g., $70 \%$ ), with levels of NDSF as low as $6-10 \%$, whereas NDSF predominates in soybean hulls, beet pulp, citrus pulp, and pasture forbs including legumes (Hall, 2000). While the concentration of pectin in alfalfa cell walls is reported to range from 100 to $200 \mathrm{~g} \mathrm{~kg}^{-1}$ in stems and from 250 to $300 \mathrm{~g} \mathrm{~kg}^{-1}$ in leaves (Hatfield and Weimer, 1995), the pectin concentrations of grasses is typically only $10 \mathrm{~g} \mathrm{~kg}^{-1} \mathrm{DM}$ (Hatfield et al., 1999). Pectins are complex polysaccharides that include galacturonic acid, arabinose, galactose, xylose, rhamnose, glucuronic acid, and fucose (Van Soest, 1994) and are a dominant fraction of NDSF. Preliminary analyses suggest that the pectin component of NFC varies in response to growth environment (MacAdam, 2019). Compared with the NFC totals of $42 \%$ in leaves and $13 \%$ in stems of New York-grown alfalfa (Hall et al., 1999), the total NFC concentrations in the leaves and stems of alfalfa grown in the Mountain West were 42 and 37\%, respectively, with as much as $20 \%$ of the dry matter (DM) of both leaves and stems estimated to be pectins (MacAdam, 2019).

Few studies of forages report NFC concentrations, but focus instead on the concentration of starch and WSC, which ferment rapidly to lactic acid in the rumen, lowering the $\mathrm{pH}$ (Strobel and Russell, 1986; Ben-Ghedalia et al., 1989). In contrast, the fermentation of pectin, a dominant component of the NDSF fraction of dried citrus and beet pulps, results in a high ratio of acetate to propionate plus little or no lactate, and thus pectin fermentation does not lower rumen $\mathrm{pH}$ (Hall et al., 1998; Hall, 2000). Fermentation of the NFC fraction of forages begins rapidly and proceeds at greater rates than the fermentation of the NDF fraction (Titgemeyer et al., 1992; Hall et al., 1998; Arthington et al., 2002) with the added benefit that increments in the concentration of NFC in legumes promotes a glucogenic fermentation and enhances microbial $\mathrm{N}$ synthesis in the rumen (Berthiaume et al., 2010).

Non-fiber carbohydrates are $\sim 98 \%$ digestible (Van Soest, 1967), but components vary in their fermentation and digestion characteristics and thus in the profile of metabolizable nutrients that they provide (Leiva et al., 2000). For instance, ruminal fermentation of NDSF such as pectic substances is extensive (Titgemeyer et al., 1992) and rapid (Hatfield and Weimer, 1995) although fermentation of pectin slows if rumen $\mathrm{pH}$ decreases, while fermentation of starch and sucrose continues, lowering rumen $\mathrm{pH}$ even further (Strobel and Russell, 1986). The metabolizable nutrients produced in the rumen by sugars and starch are enriched in propionate, which is converted to glucose in the liver, whereas those produced by NDSF are enriched in acetate, which is lipogenic (Hall, 2000). Pectin ferments more rapidly in the rumen than starch, so pectin-rich diets result in less microbial production per unit of carbohydrate digested than starch-rich diets. Dairy diets enriched in pectins resulted in greater milk fat while diets enriched in starch resulted in greater milk protein, either because pectin is digested more rapidly than starch, thereby yielding less microbial protein, or because a greater proportion of absorbed protein is utilized for glucose production in pectin-rich diets (Leiva et al., 2000).

Neutral detergent-soluble fiber can represent a key source of energy in beef and sheep finishing diets as well as in dairy cow diets (Leiva et al., 2000; Caparra et al., 2007; Favarola et al., 2016), with fewer negative effects on rumen fermentation (e.g., reduction of ruminal $\mathrm{pH}$ ) than starchrich diets (Bampidis and Robinson, 2006). Nevertheless, diets with high NDSF may yield less metabolizable protein than those containing greater amounts of starch (Rosendo et al., 1999), although other studies have observed improved microbial synthesis (Zhao et al., 2013) and flow of microbial crude protein (CP) to the small intestine (Huhtanen, 1988), with reductions in urinary $\mathrm{N}$ excretion (Gressley and Armentano, 2005) and improved animal performance (Kim et al., 2007) in response to supplemental NDSF. Legume forages are enriched in protein, so diets with elevated NDSF from legumes would contain sufficient metabolizable protein to complement the energy supplied by the NDSF fraction. While NDSF is almost entirely digestible by rumen microbes, the rumen digestibility of the NDF in feeds varies enormously, ranging from $13 \%$ for peanut hulls to $78 \%$ for soybean meal (Varga and Hoover, 1983). Almost all the information available on NDSF is derived from studies that use products rich in this fraction (such as beet pulp) added to feedlot rations.

A significant gap in knowledge exists regarding the influence of NDSF on the nutrition of grazing livestock or the agroecological variables that impact the concentration of this fraction in forages, despite the fact that increasing the use of legumes with elevated NDSF and reducing the use of starchrich concentrates would enhance the sustainability of foragebased livestock production systems. A particular benefit of NFC in forages over grain is reduced competition for grain in beef production systems. Such a benefit is already being recognized in dairy systems; Münnich et al. (2018) calculated that substituting beet pulp (a source of NDSF) for maize grain in one-third of a Simmental dairy cow diet on a dry matter (DM) basis reduced human-edible food use by about $37 \%$ while increasing fiber digestibility.

\section{Effect of Neutral Detergent-Soluble Carbohydrates on Performance of Beef Cattle}

While it is known that the amount and composition of NFC fractions of ruminant diets serve a different function from structural carbohydrates, study of the NFC fraction of forages has largely been limited to WSC or starch and not on the effects of other fractions such as NDSF on rumen function. However, it has been demonstrated that differences in dietary starch and pectin result in differences in protein and fat production in ruminants. It has also been demonstrated that digestion of NDF decreases when forage diets are supplemented with either starch or pectin at high levels, likely due to a decrease in $\mathrm{pH}$ below 6.2 and competition 
for $\mathrm{N}$ between NFC- and NDF-digesting microorganisms (Cameron et al., 1991; Grant and Mertens, 1992).

Newly developed grass cultivars, such as high-sugar ryegrass varieties, have been bred for greater contents of WSC to increase the supply of energy to the rumen and the synchrony of energy with $\mathrm{CP}$ to increase the efficiency of $\mathrm{N}$ use in pasture-based systems (Edwards et al., 2007). When the effects of different levels of the water-soluble carbohydrate component of NFC in perennial ryegrass (Lolium perenne L.) on rumen metabolism and $\mathrm{N}$ absorption were investigated with grazing Hereford $\times$ Friesian steers, Lee et al. (2002) reported that DM intake increased for cattle grazing high-sugar perennial ryegrass, contributing to higher flows of non-ammonia $\mathrm{N}$ to the duodenum, and increased the absorption of amino acids from the small intestine. Conversely, in a study conducted with ruminally cannulated Holstein-Friesian steers, the addition of sucrose to diets based on grass silage at $90 \mathrm{~g} / \mathrm{kg}$ DM only tended to increase OM digestion in the rumen, but did not affect intake or digestion of NDF organic matter (Owens et al., 2008).

The majority of the work that investigated the effects of NFC on the digestion efficiency and performance of beef cattle was performed by direct supplementation with carbohydrates rather than by employing forages containing varying types and concentrations of NFC. Feeding supplemental NFC, in particular at high rates, without providing additional rumendegradable protein in diets, may potentially hinder forage fiber digestion (Arroquy et al., 2004). Most studies suggest that the efficiency of NFC supplementation may be optimized by providing supplemental rumen-degradable protein in conjuction with NFC in diets (Heldt et al., 1999).

Overall, increases in the concentration of NFC to levels commonly used in total mixed rations positively affects animal performance. For instance, Ramos-Aviña et al. (2018) reported higher average daily gain of Holstein steers fed diets containing high concentrations of NFC in an indoor feeding study, without affecting DM intake. Nevertheless, there is a paucity of information on the effect of the NDSF fraction of forages on animal performance and in particular, on meat quality. The majority of the studies that investigated the effects of NDSF used either citrus pulp or beet pulp as the main source, while only a few studies compared forages containing different amounts of these carbohydrates. Use of citrus pulp, a byproduct with high contents of NDSF, has been associated with positive effects on ruminal fermentation (Pinzon and Wing, 1976), fiber digestion (Miron et al., 2002), and microbial protein synthesis (Ariza et al., 2001). Supplementation of beef cattle that were fed a tropical grass-based diet (Cynodon nlemfuensis Vanderyst) with increasing amounts of pelleted citrus pulp had a positive effect on digestibility of total diet dry matter and organic matter owing to greater NDSF content (predominantly pectins) (Villarreal et al., 2006). Huhtanen (1988) also reported greater rumen and total track digestibility of NDF when cannulated cattle were fed beet pulp-containing diets as compared to barley-based (high starch) diets. In a study that compared the effects of starch from cereals with isoenergetic diets containing soluble fiber from beet pulp as $50 \%$ of the diet DM on the fattening characteristics of Belgian Blue, Limousin and Aberdeen Angus cattle, no diet effect was found on animal performance, DM intake, or meat quality (Cuvelier et al., 2006). In a comparison of the digestion of isonitrogenous diets in sheep supplemented with either pectin or starch, Ben-Ghedalia et al. (1989) found that rumen $\mathrm{pH}$ was significantly greater (6.42 vs. 6.18$)$ and rumen ammonia concentration was significantly less (17 vs. $24 \mathrm{mg} / 100 \mathrm{~mL}$ ) for pectin- vs. starch-supplemented sheep.

\section{Effect of Non-fiber Carbohydrates on Meat Quality}

MacAdam and Villalba (2015) reported that beef cattle grazing the perennial legume birdsfoot trefoil (Lotus corniculatus L.), with an NFC concentration of $40 \%$ of dry mass, had nearly twice the gain during finishing compared with beef cattle grazing grass pastures. Consumer sensory panels rated steaks from these high-NFC legume-finished cattle comparable to grain-finished cattle for tenderness and juiciness due to greater deposition of intramuscular fat, and steaks from both legume- and grainfinished cattle were preferred over steaks from grass-finished cattle (Chail et al., 2016). When the NFC concentrations of the grain and legume pasture diets in this study were compared, their concentrations were both about $40 \%$, twice that of the grass pasture diet. When the NFC concentration of hay made from alfalfa and other perennial legumes grown in the Mountain West was measured, it ranged from 36 to $40 \%$ (Stewart et al., 2019) and 42 to $48 \%$ for the same legumes sampled in pastures (MacAdam, 2019). Therefore, NFC losses during field curing are $~ 5 \%$ of dry mass, and perennial legume hay has an NFC concentration more similar to corn silage or beet pulp ( 36 and $38 \%$, respectively) than to conventional alfalfa hay (26\%), based on numerous samples from commercial dairy farms located in the Central Valley of California (Getachew et al., 2004).

Acetate and propionate from rumen fermentation can both be directed to fat deposition in cattle, but propionate must first be converted to glucose in the liver, which is an energyconsuming process (Smith and Johnson, 2014). In young cattle, glucose is used preferentially for intramuscular fat accumulation (marbling), while acetate is used preferentially for subcutaneous (back) fat deposition (Smith and Crouse, 1984). However, as cattle mature, the use of acetate in marbling increases and the use of glucose decreases (Choi et al., 2014). Eight-month-old Angus steers on high-energy (70\% ground corn) diets or lowerenergy (corn silage) diets had similar DM intake, marbling, and Longissimus thoracis et lumborum cross-sectional area. However, the steers fed ground corn carried 30\% more backfat at 18 months than the corn silage-fed steers (Smith and Crouse, 1984). Intramuscular fat deposition depends on a sufficient supply of energy, whether in the form of glucose or acetate, and excess energy will be accumulated as backfat, at least in Angus cattle (Smith and Johnson, 2014). These data suggest that increasing NFC in the form of pectins is more desirable than by increasing starch.

Corn grain is estimated to contain 6-10\% NDSF, $0-5 \%$ sugars, and $70 \%$ starch; in contrast, citrus pulp and beet pulp typically contain about $30 \%$ NDSF, $10 \%$ sugars, and $1 \%$ starch on a dry matter basis (Hall, 2000). The perennial 


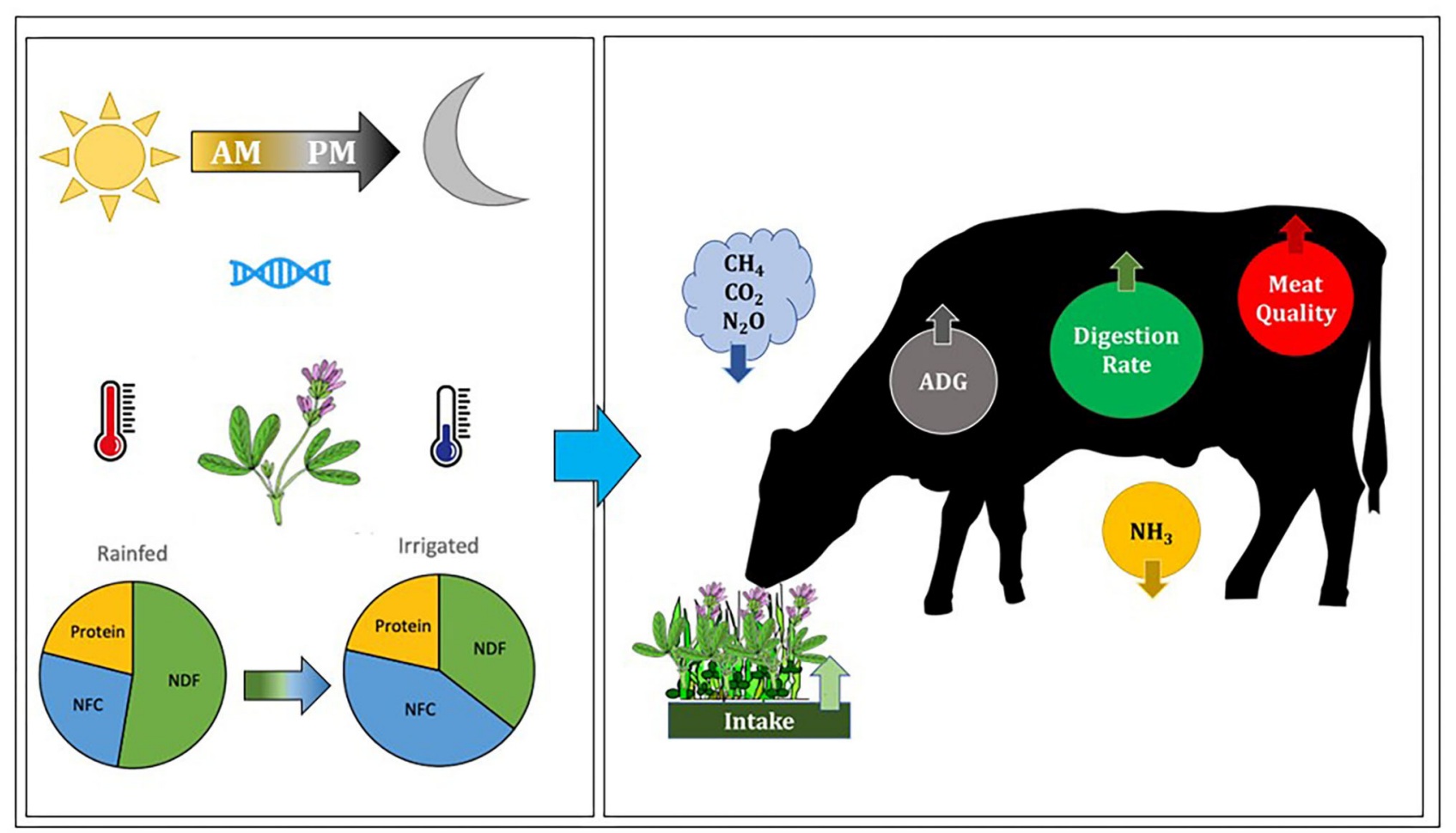

FIGURE 2 | Factors that increase the NFC of alfalfa and other perennial legumes include harvesting in the afternoon rather than the morning, breeding for greater pectin concentration, and greater photosynthesis combined with reduced aerobic respiration. Relatively dry climates in which forages are grown under irrigation are exposed to long hot sunny days with more solar radiation and therefore produce more photosynthate than more humid environments, and lower relative humidity results in cool nighttime temperatures that reduce aerobic respiration. The reduced fiber and increased NFC concentration of these forages result in more rapid digestion and emptying of the rumen, leading to greater intake, and increased ruminant production of meat and milk. Increased NFC also results in better protein utilization, increased nitrogen retention, less nitrogen excretion, and reduced enteric emissions of methane and carbon dioxide.

forage legumes cultivated under irrigation in the western US contain NFC concentrations similar to corn silage (35-45\%), but starch and WSC concentrations were not elevated (MacAdam, 2019) and OA concentrations tend not to vary greatly, so elevated NFC in perennial legumes is thought to be due to greater pectin concentrations. In ruminant studies where dietary starch was replaced by beet pulp or citrus pulp, both rich in NDSF, the resulting blood glucose of dairy cows (Belibasakis and Tsirgogianni, 1996; Münnich et al., 2018) and lambs (Bhattacharya and Harb, 1973; Sharif et al., 2018) was unaffected.

\section{ENVIRONMENTAL BENEFITS OF NON-FIBER CARBOHYDRATES}

In addition to reducing the use of grain in ruminant diets, the use of forages with elevated NFC, such as perennial legumes cultivated in the Mountain West, will benefit the environment by increasing ruminant production efficiency relative to cattle fed forages with lower NFC concentrations (Figure 2). In a study of ewes (Barrios-Urdaneta et al., 2003) where $85 \%$ of the diet dry matter consisted of barley grain or dried citrus pulp, the citrus pulp diet significantly reduced excretion of nitrogen in the urine, but feces nitrogen excretion was unchanged. Forages are typically high in rumen-degradable protein but low in nonstructural carbohydrates, causing rumen microbes to use protein as an energy source and resulting in excess rumen ammonia $\left(\mathrm{NH}_{3}^{+}\right)$-nitrogen (Satter and Roffler, 1975) and excretion of increased amounts of urea, the predominant nitrogen-containing compound in the urine. Excretion of excess nitrogen results in both a metabolic cost to the animal (Lobley and Milano, 1997) and increased environmental pollution. Urea is rapidly hydrolyzed to ammonia that is converted to nitrate $\left(\mathrm{NO}_{3}^{-}\right)$in the soil (Haynes and Williams, 1993), where it can be leached to groundwater and waterways (Leip et al., 2015). Large losses of $\mathrm{NH}_{3}^{+}$also occur by volatilization after urination, as well as losses of nitrous oxide during the denitrification process (Lee et al., 2014). Thus, providing feeds sufficiently high in NFC to match rumen-degradable protein concentration has been proposed as a potential management approach for reducing nitrogen losses (Dalley et al., 2017).

In pasture-based production systems, feeding grass varieties containing elevated WSC, a subset of NFC, reduced nitrogen excretion in urine and feces by providing sufficient readily available (and synchronous) energy for microbial capture of digested grass protein to increase microbial protein synthesis (Miller et al., 2001; Ellis et al., 2012). High-sugar ryegrass, chicory, 
and plantain varieties have also been used in pasture systems to achieve such goal (Totty et al., 2013; Bryant et al., 2020; Wilson et al., 2020). The digestibility and composition of forages with greater NFC concentrations have a substantial impact on methane $\left(\mathrm{CH}_{4}\right)$ production from ruminants through more rapid ruminal fermentation and passage rates per unit of feed (Figure 2) (Hindrichsen et al., 2005). Knapp et al. (2014) reported that a 5\% increase in apparent total-tract NDF digestibility led to a $5 \%$ decrease in $\mathrm{CH}_{4}$ methane production per unit of energycorrected milk due to greater yield of volatile fatty acids relative to increases in $\mathrm{CH}_{4}$, and increased milk yield.

\section{FACTORS AFFECTING THE CONCENTRATION OF NFC IN FORAGES}

\section{Maturity}

Plant maturity at the time of harvest is one of the primary factors decreasing nutritive value of forages in both grazed and conserved forage/livestock production systems, at least in humid environments. The nutritive value of forages declines with increasing plant maturity due to accummulation of structural carbohydrates (NDF) and an increasing stem-to-leaf ratio. In general, as alfalfa matures, the proportions of fiber, and lignin increase and the proportions of protein and NFC decrease (Martin et al., 2004). It should be noted that Martin et al. (2004), working in Wisconsin, report that "exceptional quality" alfalfa hay is expected to have an NFC concentration of $31.5 \%$, while NFC concentrations of Mountain West alfalfa hay are routinely 36-39\% (MacAdam and Yost, 2020). Yu et al. (2003), working in Saskatchewan, reported that the changes in carbohydrate fractions as plant maturity advanced were slight in alfalfa, and there were no changes in timothy grass (Phleum pratense L.). Similarly, alfalfa cultivated in the northern Mountain West maintained a constant NFC concentration of about $40 \%$ as it matured from the vegetative to the early bloom stage (MacAdam, 2020).

\section{Defoliation}

Harvest management of forages, in particular the defoliation time, frequency and intensity, affects plant regrowth, persistence, morphological structure, and chemical composition. Under frequent defoliation, either in the form of grazing or mechanical harvesting, pasture grasses produce smaller tillers but at higher density (Matthew et al., 1996). Therefore, non-structural carbohydrates of both harvested forage material and remaining stubble may be depleted by recurrent defoliation because the NFC stored in the stubble of plants provides energy for regrowth (Donaghy et al., 2008; Alderman et al., 2011). Overall, the watersoluble carbohydrate component of NFC is reduced in grasses as defoliation severity increases (Lee et al., 2008). Conversely, as defoliation interval increases, the nutritive value of grasses declines along with digestibility, but at varying rates depending on the grass species (Turner et al., 2006).

A number of studies reported substantial changes in chemical composition of winter annual small grains in relation to grazing and defoliation when used as supplementary off-season grazing as well as grain crops. Defoliation of such forages in early vegetative stages may have a positive effect on the nutritive value of the regrown forage material (Jacobs et al., 2009; Keles et al., 2013). Cazzato et al. (2012) reported that mechanical harvest of vegetative triticale in winter resulted in an increase in NDF but a decrease in lignin at the heading stage. Similarly, Jacobs et al. (2009) reported varying rates of increase in metabolizable energy and WSC concentrations of oat and barley varieties at silage harvest following two spring grazings at the tillering and stem elongation stages in a dual purpose management system. Ates et al. (2017) also reported that straw of spring-defoliated triticale, wheat and rye had less NDF and acid detergent fiber (ADF) but greater $\mathrm{CP}, \mathrm{NFC}$, and metabolizable energy concentrations than straw from undefoliated crops. However, Francia et al. (2006) reported no substantial changes in the nutritive value of oat or barley regrowths in relation to spring defoliation or grazing management in the Mediterranean region.

\section{Breeding Programs}

Extensive work has been devoted to improving the fiber digestibility of forage species to improve ruminant productivity. A number of breeding studies focused on increasing the NFC concentrations of forage grasses and legumes to develop varieties with high digestibility. In particular, increasing pectin concentration as the major component of NDSF in alfalfa (Medicago sativa L.) has been the focus of several breeding programs (Tecle et al., 2006), one resulting in a patent application for High Pectin Alfalfa (Hatfield et al., 2006). The patent application reported that the improved alfalfa had a pectin concentration consistently 2-3\% greater than the control which resulted in an estimated increase of between 90 and $900 \mathrm{~kg}$ of milk per acre of alfalfa.

\section{Sound}

A recent study reported that plants increase nectar sugar concentration in response to pollinator sounds (Veits et al., 2019). Although no information was provided on NFC concentrations in the leaves of these plants, further studies may investigate effects of pollinator sounds on NFC concentrations in both grazed and conserved forages.

\section{Photosynthesis}

The NFC concentration of plants is affected by a wide range of environmental factors such as light and temperature. Photosynthesis responds to diurnal fluctuations in solar radiation, and affects the non-structural carbohydrate concentration of plants through accumulation of starch in leaves during the day that provides the energy for plant growth and maintenance processes. Consequently, greater concentrations of NFC in afternoon compared with morning harvests have been reported in pasture grasses and legumes. As the day progresses, the rate of carbon fixation progressively exceeds carbon export from leaves, and the benefit of greater concentrations of NFC in forages is therefore demonstrated by feeding alfalfa harvested in the afternoon compared with alfalfa harvested in the morning. Elevated NFC in afternoon-cut forage resulted in greater DMI and milk yield (Brito et al., 2008), nitrogen use efficiency (Berthiaume et al., 2010), and rumen bacterial protein synthesis 
(Brito et al., 2009). Feeding alfalfa genotypes with elevated NFC during continuous culture rumen fermentation likewise resulted in significant increments $(+14 \%)$ in the synthesis of bacterial protein (Berthiaume et al., 2010). Thus, greater concentrations of readily accessible carbohydrates in the form of NDSF can enhance DM intake and rumen fermentable energy, which in turn improves ruminant performance and nitrogen utilization in beef cattle while reducing urinary nitrogen outputs (Figure 2).

Harvesting the grass timothy (Phleum pratense L.) in the afternoon as compared to the morning resulted in higher NFC, mainly sucrose concentrations, and decreased ADF and NDF concentrations (Bertrand et al., 2008). Similar results were obtained with a number of grass and legume species from a range of functional and structurual groups (Fisher et al., 1999, 2002; Griggs et al., 2005; Yari et al., 2014) that were harvested in the afternoon compared with the morning. Concentrations of nonstructural carbohydrates, the cell contents subset of NFC, also vary depending on forage species and growth period (Pelletier et al., 2010). For instance, Owens et al. (1999) reported that starch accounted for most of the daily change in non-structural carbohydrates in fresh alfalfa, whereas in red clover (Trifolium pratense L.), quantitative increases in sugar and starch had an equal impact on non-structural carbohydrate concentration.

Management practices have been developed to take advantage of higher non-structural carbohydrates concentrations of pasture species in the afternoon. For instance, having a sufficiently high non-structural carbohydrates concentration is critical for successfully ensiling forages and the resultant silage quality, in particular for forages that are difficult to ensile such as alfalfa and red clover (Owens et al., 2002). Harvesting forages in the afternoon may improve the ensiling process by providing additional non-structural carbohydrates for the rapid growth of lactic acid-producing bacteria. This would in turn reduce DM losses, improve aerobic stability and reduce clostridial spoilage that occurs when lactic acid production occurs too slowly.

Livestock are able detect the difference in non-structural carbohydrates concentrations of plant species, and exhibit preference for forages harvested in the afternoon (Fisher et al., 1999). Similarly, allocating new pasture strips in the afternoon rather than morning has been reported to increase the milk yield of dairy cows (Orr et al., 2001) and liveweight gains of beef heifers (Gregorini et al., 2008).

\section{Temperature and Altitude}

Temperature has a strong influence on plant growth, development and chemical composition (Jung, 1989; Buxton, 1996). The increased lignification of individual plant cells and in particular reduced fiber digestibility at higher temperatures in both tropical and temperate forage species was consistently reported with the effect being less profound in tropical species in a number of studies (Akin et al., 1987; Wilson et al., 1991; Buxton and Fales, 1994). Extrapolating the research data from replicated studies, the negative effect of temperature on forage quality was also highlighted in a few recent review papers that forecasted decreasing forage digestibility due to rising global temperatures (Dumont et al., 2015; Lee et al., 2017; Ghahramani et al., 2019). Physiologically, lignin synthetic enzyme activities increase in plants as a reponse to increasing temperatures (Buxton and Fales, 1994), while higher proportions of non-structural carbohydrates are metabolized into structural carbohydrates (Deinum and Knoppers, 1979). Overall, lignification was reported to be more extensive in stem than leaf tissues (Wilson, 1983a) and plants generally produced smaller leaves at increasing temperatures, leading to reduced leaf-to-stem ratios, an increased cell wall fraction, and lower dry matter digestibility (Wilson and Minson, 1983). Ultimately, non-structural carbohydrate concentrations of forages even at comparable plant maturity stages were lower at high temperatures (Xu and Huang, 2000).

The nutritive value of forages grown at higher altitudes is understood to be superior to forages grown at lower altitudes (Old et al., 2018). However, the apparent effects of altitude are more likely related to cooler growing-season temperatures at high elevations. Plant aerobic respiration uses the carbohydrates synthesized by photosynthesis for plant growth and maintenance (MacAdam and Nelson, 2017) and aerobic respiration decreases with temperature, increasing the accumulation NFC. It would be challenging to design a study to separate the effects of altitude and temperature on irrigated, field-grown legumes. However, irrigated alfalfa grown in Utah at 1,200,1,500,1,800, and 2,100 m a.s.l. did not differ in NDF, NFC, or TDN, which averaged 31, 37, and 69\%, respectively (MacAdam and Yost, 2020). Early lines of low-lignin lines of alfalfa grown at an altitude of $15 \mathrm{~m}$. a.s.l. at Davis, CA averaged NDF, NFC or TDN concentrations of 29, 39, and $71 \%$, respectively (Putnam et al., 2017). While dissimilar in altitude, the common element of climate in these locations is the $20^{\circ} \mathrm{C}$ difference in mid-summer day-night temperatures. Under irrigation, alfalfa thrives at in daytime temperatures above $30^{\circ} \mathrm{C}$. while night time temperatures in the range of $10-15^{\circ} \mathrm{C}$ result in a reduction in root and shoot respiration (Atkin and Tjoelker, 2003) with no deleterious effect on alfalfa.

\section{Water Availability}

In general, the nutritive value of perennial forages growing under moderate water deficits tends to be greater than for forages grown under full irrigation (Wilson, 1982, 1983a,b), provided that the deficit was not severe and was initiated early in herbage growth (Buxton, 1996; Reddy et al., 2003). In contrast, long or extreme droughts inhibit tillering and branching, accelerate the death of tillers and senescence of leaves, and relocate protein, nitrogen, and NFC from leaves to roots, reducing the nutritive value of the forage (Buxton, 1996; Durand et al., 2010; Liu et al., 2018).

Under well-watered conditions, the nutritive value of alfalfa declines with maturation (Kalu and Fick, 1981), but mean maturity stage decreases with increasing water stress (Van Soest, 1994). Water deficits may directly reduce the rate of plant maturation (Wilson and Ng, 1975; Wilson, 1982; Buxton, 1996). However, Halim et al. (1989) demonstrated that increments in stem protein concentration and reductions in cellulose concentration in alfalfa stems and leaves under water stress were not fully accounted for by differences in plant maturity. These authors attributed improvements in forage quality to greater leafto-stem ratio in water-stressed plants, given that water stress has the greatest effect on reducing stem growth (Halim et al., 
1989). Under moderate water restrictions, in vitro dry matter digestibility of alfalfa is greater and concentration of NDF is less under prolonged water deficits that reduce plant water potential than in control plants grown without a water deficit (Halim et al., 1989; Peterson et al., 1992). Research with other legumes like birdsfoot trefoil, sainfoin (Onobrychis viciifolia L.), red clover (Trifolium pratense L.) and cicer milkvetch (Astragalus cicer L.) show similar patterns in response to water stress to those described for alfalfa (Peterson et al., 1992; Küchenmeister et al., 2013), although alfalfa yields tend to be less affected by drought than other species. When these alternative legumes were droughted, they produced biomass with lower concentrations of $\mathrm{ADF}, \mathrm{NDF}$, and lignin than alfalfa, with birdsfoot trefoil and cicer milkvetch producing the highest quality forage (Peterson et al., 1992). Nevertheless, because of its superior yield and persistence under drought, it was concluded that alfalfa would produce more nutrients per unit of area than the alternative legumes (Peterson et al., 1992).

It has been hypothesized that cell wall development during relatively severe water stress may be inhibited because more carbon in labile forms, like the sugars fixed by photosynthesis, is needed for osmoregulatory purposes (Wilson, 1982). In support of this idea, the concentration of glucose in cell walls tends to decline whereas the concentration of structural sugars tends to increase in forages during dry compared with wet years (Albrecht et al., 1987), and the concentration of cell wall monosaccharides is more sensitive to plant environment than other cell wall components (Buxton et al., 1987).

This has been confirmed by more recent controlled environment studies showing increments in the concentration of WSC due to water stress in forages like birdsfoot trefoil, sainfoin, white clover and perennial ryegrass (Küchenmeister et al., 2013). An increase in the concentration of WSC in plants will reduce the water potential and maintain uptake of soil water under drought stress (Morgan, 1984; Nakayama et al., 2007), an osmotic adjustment mechanism triggered in response to drought (Da Costa and Huang, 2006). Crude protein concentration in legumes tends to increase with water deficit in stems, but it decreases in leaves (Halim et al., 1989). Increased leaf senescence with water stress and translocation of amino acids to other plant parts (including stems) could explain this pattern (Halim et al., 1989). As a result, however, the ratio of CP to WSC decreases in forages under drought (Liu et al., 2018), resulting in greater $\mathrm{N}$ retention and less urinary excretion by ruminants (Moorby et al., 2006). Greater WSC concentrations and lower cell wall concentrations also result in greater forage digestibility, leading to increased intake.

Labile forms of carbon for osmoregulatory purposes may not only include increments of WSC, which are just a fraction of the non-structural carbohydrates present in forages, but also increments in OA, starch, and/or the NDSF fraction. Despite these benefits, no critical research has been conducted to explore the influence of water deficit on NFC, and in particular on NDSF, a significant component of legumes cultivated in cooler, drier environments. Moderate water deficits increase the concentrations of NFC in legumes and in grass-legume mixes, leading to enhancements in digestibility, animal performance and product quality, while improving the balance between $\mathrm{NH}_{3}$ nitrogen and energy supply to the rumen. The latter increases nitrogen retention and reduces the excretion of urinary nitrogen to the environment (Figure 2).

\section{CONCLUDING REMARKS AND FUTURE DIRECTIONS}

Despite the aforementioned ability of forage legume shoots to accumulate NFC to levels comparable to corn silage or citrus pulp in dry, cool environments, and the potential benefits to ruminant meat and milk productivity, very little critical research has been conducted to explore the breeding potential or to define critical management practices and ecological conditions (i.e., climate, elevation, soil water status) that result in elevated concentrations of NFC in forages. There is particular value in studying the accumulation of pectins in legumes and non-leguminous forbs as a source of energy for rumen microbes equivalent to starch but without the risk of lowering rumen $\mathrm{pH}$. We hypothesize that moderate water deficits and other conditions that increase the concentrations of NFC in legumes and in grass-legume mixes will enhance the kinetics of rumen fermentation and increase the digestibility of forages by improving the synchrony of energy and protein supply, with concomitant increased nitrogen retention, improved feed conversion efficiencies, reduced greenhouse gas emissions, and improved performance of ruminants (Figure 2). Defoliation in the afternoon rather than in the morning may contribute to increments in the concentration of NFC in all forages, and likely to increased pectin concentrations in legumes. Alfalfa has been successfully selected for greater pectin concentrations but no high-pectin cultivars have been released. Elevated photosynthetic rates combined with reduced aerobic respiration under irrigation in dry climates with long hot sunny days (maximizing solar radiation) results in the accumulation of more photosynthate than under humid environments, with the corollary of a better balance between the energy to protein ratio supplied to the rumen. Lower relative humidity typical of high altitudes results in cool nighttime temperatures that reduce aerobic respiration resulting in greater residual shoot NFC concentration and proportionally reduced fiber in legumes. Ecoregions with such characteristics should be identified so forage and ruminant producers can exploit these locations for the production and marketing of forages that enhance the productivity and sustainability of livestock production systems. Ruminal $\mathrm{NH}_{3}$-nitrogen concentration typically decreases as dietary NFC concentration increases (Lee et al., 2002) and increased availability of fermentable energy in the rumen stimulates microbial growth (Brito et al., 2009), which improves animal performance. We have demonstrated that forage NFC concentrations can be significantly increased, resulting in improvements in ruminant performance and reduced carbon and nitrogen footprints, particularly when grazing nitrogen-rich legumes (Lagrange et al., 2020), representing a win-win situation for ruminant production systems. 


\section{AUTHOR CONTRIBUTIONS}

JV, SA, and JM drafted the manuscript and wrote the review. All authors contributed to the article and approved the submitted version.

\section{REFERENCES}

Akin, D. E., Fales, S. L., Rigsby, L. L., and Snook, M. E. (1987). Temperature effects on leaf anatomy, phenolic acids, and tissue digestibility in tall fescue 1. Agron. J. 79, 271-275. doi: 10.2134/agronj1987.00021962007900020019x

Albrecht, K. A., Wedin, W. F., and Buxton, D. R. (1987). Cell-wall composition and digestibility of alfalfa stems and leaves 1. Crop Sci. 27, 735-741. doi: 10.2135/cropsci1987.0011183X002700040027x

Alderman, P. D., Boote, K. J., Sollenberger, L. E., and Coleman, S. W. (2011). Carbohydrate and nitrogen reserves relative to regrowth dynamics of 'Tifton 85 'bermudagrass as affected by nitrogen fertilization. Crop Sci. 51, pp.1727-1738. doi: 10.2135/cropsci2010.09.0516

Allen, M. S., and Mertens, D. R. (1988). Evaluating constraints on fiber digestion by rumen microbes. J. Nutr. 118, 261-270. doi: 10.1093/jn/118.2.261

Archimède, H., Sauvant, D., and Schmidely, P. (1997). Quantitative review of ruminal and total tract digestion of mixed diet organic matter and carbohydrates. Reproduct. Nutri. Deve. 37, 173-189. doi: 10.1051/rnd:19970205

Ariza, P., Bach, A., Stern, M. D., and Hall, M. B. (2001). Effects of carbohydrates from citrus pulp and hominy feed on microbial fermentation in continuous culture. J. Anim. Sci. 79, 2713-2718. doi: 10.2527/2001.79102713x

Arroquy, J. I., Cochran, R. C., Villarreal, M., Wickersham, T. A., Llewellyn, D. A., Titgemeyer, E. C., et al. (2004). Effect of level of rumen degradable protein and type of supplemental non-fiber carbohydrate on intake and digestion of low-quality grass hay by beef cattle. Anim. Feed Sci. Technol. 115, 83-99. doi: 10.1016/j.anifeedsci.2004.02.005

Arthington, J. D., Kunkle, W. E., and Martin, A. M. (2002). Citrus pulp for cattle. Vet. Clin. N. Am. 18, 317-326. doi: 10.1016/S0749-0720(02)00023-3

Ates, S., Keles, G., Demirci, U., Dogan, S., and Ben Salem, H. (2017). Biomass yield and feeding value of rye, triticale, and wheat straw produced under a dual-purpose management system. J. Anim. Sci. 95, 4893-4903. doi: $10.2527 /$ jas 2017.1888

Atkin, O. K., and Tjoelker, M. G. (2003). Thermal acclimation and the dynamic response of plant respiration to temperature. Trends Plant Sci. 8, 343-351. doi: 10.1016/S1360-1385(03)00136-5

Bampidis, V. A., and Robinson, P. H. (2006). Citrus by-products as ruminant feeds: a review. Anim. Feed Sci. Technol. 128, 175-217. doi: 10.1016/j.anifeedsci.2005.12.002

Barrios-Urdaneta, A., Fondevila, M., and Castrillo, C. (2003). Effect of supplementation with different proportions of barley grain or citrus pulp on the digestive utilization of ammonia-treated straw by sheep. Anim. Sci. 76, 309-317. doi: $10.1017 /$ S1357729800053558

Belibasakis, N. G., and Tsirgogianni, D. (1996). Effects of dried citrus pulp on milk yield, milk composition and blood components of dairy cows. Anim. Feed Sci. Technol. 60, 87-92. doi: 10.1016/0377-8401(95)00927-2

Ben-Ghedalia, D., Yosef, E., Miron, J., and Est, Y. (1989). The effects of starch- and pectin-rich diets on quantitative aspects of digestion in sheep. Anim. Feed Sci. Technol. 24, 289-298. doi: 10.1016/0377-8401(89)90150-8

Berthiaume, R., Benchaar, C., Chaves, A. V., Tremblay, G. F., Castonguay, Y., Bertrand, A., et al. (2010). Effects of nonstructural carbohydrate concentration in alfalfa on fermentation and microbial protein synthesis in continuous culture. J. Dairy Sci. 93, 693-700. doi: 10.3168/jds.200 9-2399

Bertrand, A., Tremblay, G. F., Pelletier, S., Castonguay, Y., and Bélanger, G. (2008). Yield and nutritive value of timothy as affected by temperature, photoperiod and time of harvest. Grass Forage Sci. 63, 421-432. doi: 10.1111/j.1365-2494.2008.00649.x

Bhattacharya, A. N., and Harb, M. (1973). Dried citrus pulp as a grain replacement for Awasi lambs. J. Anim. Sci. 36, 1175-1180. doi: 10.2527/jas1973.3661175x

\section{ACKNOWLEDGMENTS}

This research was supported by the Utah Agricultural Experiment Station, Utah State University, and approved as journal paper number 9449 .

Brito, A. F., Tremblay, G. F., Bertrand, A., Castonguay, Y., Bélanger, G., Michaud, R., et al. (2008). Alfalfa cut at sundown and harvested as baleage improves milk yield of late-lactation dairy cows. J. Dairy Sci. 91, 3968-3982. doi: 10.3168/jds.2008-1282

Brito, A. F., Tremblay, G. F., Lapierre, H., Bertrand, A., Castonguay, Y., Bélanger, G., et al. (2009). Alfalfa cut at sundown and harvested as baleage increases bacterial protein synthesis in late-lactation dairy cows. J. Dairy Sci. 92, 1092-1107. doi: 10.3168/jds.2008-1469

Bryant, R. H., Snow, V. O., Shorten, P. R., and Welten, B. G. (2020). Can alternative forages substantially reduce $\mathrm{N}$ leaching? Findings from a review and associated modelling. New Zealand J. Agric. Res. 63, 3-28. doi: 10.1080/00288233.2019.1680395

Buxton, D. R. (1996). Quality-related characteristics of forages as influenced by plant environment and agronomic factors. Anim. Feed Sci. Technol. 59, 37-49. doi: 10.1016/0377-8401(95)00885-3

Buxton, D. R., and Fales, S. L. (1994). Plant environment and quality. Forage Qual. Eval. Utiliz. 155-199. doi: 10.2134/1994.foragequality.c4

Buxton, D. R., Hornstein, J. S., and Marten, G. C. (1987). Genetic variation for forage quality of alfalfa stems. Canad. J. Plant Sci. 67, 1057-1067. doi: 10.4141/cjps87-142

Cameron, M. R., Klusmeyer, T. H., Lynch, G. L., Clark, J. H., and Nelson, D. R. (1991). Effects of urea and starch on rumen fermentation, nutrient passage to the duodenum, and performance of cows. J. Dairy Sci. 74, 1321-1336. doi: 10.3168/jds.S0022-0302(91)78288-X

Caparra,. P., Foti, F., Scerra, M., Sinatra, M. C., and Scerra, V. (2007). Solardried citrus pulp as an alternative energy source in lamb diets: effects on growth and carcass and meat quality. Small Ruminant Res. 68, 303-311. doi: 10.1016/j.smallrumres.2005.11.015

Cazzato, E., Laudadio, V., and Tufarelli, V. (2012). Effects of harvest period, nitrogen fertilization and mycorrhizal fungus inoculation on triticale $(x$ Triticosecale Wittmack) forage yield and quality. Renew. Agric. Food Syst. 27, 278-286. doi: 10.1017/S1742170511000482

Chail, A., Legako, J. F., Pitcher, L. R., Ward, R. E., Martini, S., and MacAdam, J. W. (2016). Consumer sensory evaluation and chemical composition of beef gluteus medius and triceps brachii steaks from cattle finished on forage or concentrate diets. J. Anim. Sci. 95, 1553-1564. doi: 10.2527/jas.2016.1150

Choi, S. H., Silvey, D. T., Johnson, B. J., Doumit, M. E., Chung, K. Y., Sawyer, J. E., et al. (2014). Conjugated linoleic acid ( $\mathrm{t}-10, \mathrm{c}-12)$ reduces fatty acid synthesis de novo, but not expression of gene for lipid metabolism in bovine adipose tissue ex vivo. Lipids 49, 15-24. doi: 10.1007/s11745-013-3869-0

Cosgrove, D. C. (2012). Comparative structure and biomechanics of plant primary and secondary cell walls. Front. Plant Sci. 3:204. doi: 10.3389/fpls.2012.00204

Cuvelier, C., Cabaraux, J. F., Dufrasne, I., Clinquart, A., Hocquette, J. F., Istasse, L., et al. (2006). Performance, slaughter characteristics and meat quality of young bulls from Belgian Blue, Limousin and Aberdeen Angus breeds fattened with a sugar-beet pulp or a cereal-based diet. Anim. Sci. 82, 125-132. doi: 10.1079/ASC20057

Da Costa, M., and Huang, B. (2006). Osmotic adjustment associated with variation in bentgrass tolerance to drought stress. J. Am. Soc. Horticultural Sci. 131, 338-344. doi: 10.21273/JASHS.131.3.338

Dalley, D. E., Malcolm, B. J., Chakwizira, E., and de Ruiter, J. M. (2017). Range of quality characteristics of New Zealand forages and implications for reducing the nitrogen leaching risk from grazing dairy cows. New Zealand J. Agric. Res. 60, 319-332. doi: 10.1080/00288233.2017.1345762

Deinum, B., and Knoppers, J. (1979). The growth of maize in the cool temperate climate of the Netherlands: effect of grain filling on production of dry matter and on chemical composition and nutritive value. NJAS Wageningen J. Life Sci. 27, 116-130. doi: 10.18174/njas.v27i2.17059 
Diamond, J. (2002). Evolution, consequences and future of plant and animal domestication. Nature 418, 700-707. doi: 10.1038/nature01019

Donaghy, D. J., Turner, L. R., and Adamczewski, K. A. (2008). Effect of defoliation management on water-soluble carbohydrate energy reserves, dry matter yields, and herbage quality of tall fescue. Agron. J. 100, 122-127. doi: 10.2134/agronj2007.0016

Dumont, B., Andueza, D., Niderkorn, V., Lüscher, A., Porqueddu, C., and PiconCochard, C. (2015). A meta-analysis of climate change effects on forage quality in grasslands: specificities of mountain and $\mathrm{M}$ editerranean areas. Grass Forage Sci. 70, 239-254. doi: 10.1111/gfs.12169

Durand, J. L., Gonzalez-Dugo, V., and Gastal, F. (2010). How much do water deficits alter the nitrogen nutrition status of forage crops? Nutri. Cycling Agroecosyst. 88, 231-243. doi: 10.1007/s10705-009-9330-3

Edwards, G. R., Parsons, A. J., Rasmussen, S., and Bryant, R. H. (2007). High sugar ryegrasses for livestock systems in New Zealand. Proc. New Zealand Grassland Assoc. 69, 161-171. doi: 10.33584/jnzg.2007.69.2674

Ellis, J. L., Dijkstra, J., France, J., Parsons, A. J., Edwards, G. R., Rasmussen, S., et al. (2012). Effect of high-sugar grasses on methane emissions simulated using a dynamic model. J. Dairy Sci. 95, 272-285. doi: 10.3168/jds.2011-4385

Favarola, V. R., Ezequiel, J. M. B., Almeida, M. T. C., D’Aurea, A. P., Paschoaloto, J. R., van Cleef, E. H. C. B., et al. (2016). Carcass traits and meat quality of Nellore cattle fed different non-fiber carbohydrates sources associated with crude glycerin. Animal 10, 1402-1408. doi: 10.1017/S1751731116000094

Fisher, D. S., Mayland, H. F., and Burns, J. C. (1999). Variation in ruminants' preference for tall fescue hays cut either at sundown or at sunup. J. Anim. Sci. 77, 762-768. doi: 10.2527/1999.773762x

Fisher, D. S., Mayland, H. F., and Burns, J. C. (2002). Variation in ruminant preference for alfalfa hays cut at sunup and sundown 1. Crop Sci. 42, 231-237. doi: $10.2135 /$ cropsci2002.0231

Franche, C., Lindström, K., and Elmerich, C., (2009). Nitrogen-fixing bacteria associated with leguminous and non-leguminous plants. Plant Soil 321, 35-59. doi: $10.1007 /$ s11104-008-9833-8

Francia, E., Pecchioni, N., Li Destri Nicosia, O., Paoletta, G., Taibi, L., Franco, V., et al. (2006). Dual-purpose barley and oat in a Mediterranean environment. Field Crops Res. 99, 158-166. doi: 10.1016/j.fcr.2006.04.006

Garg, N. (2009). "Symbiotic nitrogen fixation in legume nodules: process and signaling: a review," in Sustainable Agriculture 2009 (Dordrecht: Springer), 519-531. doi: 10.1007/978-90-481-2666-8_32

Getachew, G., Robinson, P. H., DePeters, E. J., and Taylor, S. J. (2004). Relationships between chemical composition, dry matter degradation and in vitro gas production of several ruminant feeds. Aniaml Feed Sci. Technol. 111, 57-71. doi: 10.1016/S0377-8401(03)00217-7

Ghahramani, A., Howden, S. M., del Prado, A., Thomas, D. T., Moore, A. D., Boyu, J.i, and Ates, S. (2019). Climate change impact, adaptation, and mitigation in temperate grazing systems: a review. Sustainability 11:7224. doi: $10.3390 /$ su11247224

Gilbert, H. J. (2010). The biochemistry and structural biology of plant cell wall deconstruction. Plant Physiol. 153, 444-455. doi: 10.1104/pp.110.156646

Grant, R. H., and Mertens, D. R. (1992). Influence of buffer $\mathrm{pH}$ and raw corn starch addition on in-vitro fibre digestion kinetics. J. Dairy Sci. 75, 2762-2768. doi: 10.3168/jds.S0022-0302(92)78039-4

Gregorini, P., Gunter, S. A., Beck, P. A., Soder, K. J., and Tamminga, S. (2008). The interaction of diurnal grazing pattern, ruminal metabolism, nutrient supply, and management in cattle. Profes. Anim. Sci. 24, 308-318. doi: 10.15232/S1080-7446(15)30861-5

Gressley, T. F., and Armentano, L. E. (2005). Effect of abomasal pectin infusion on digestion and nitrogen balance in lactating dairy cows. J. Dairy Sci. 88, 4028-4044. doi: 10.3168/jds.S0022-0302(05)73089-7

Griggs, T. C., MacAdam, J. W., Mayland, H. F., and Burns, J. C. (2005). Nonstructural carbohydrate and digestibility patterns in orchardgrass swards during daily defoliation sequences initiated in evening and morning. Crop Sci. 45, 1295-1304. doi: 10.2135/cropsci2003.0613

Grove, A. T., and Rackham, O. (2001). The Nature of Mediterranean Europe. An Ecological History. New Haven, CT: Yale University Press.

Halim, R. A., Buxton, D. R., Hattendorf, M. J., and Carlson, R. E. (1989). Waterstress effects on alfalfa forage quality after adjustment for maturity differences. Agron. J. 81, 189-194. doi: 10.2134/agronj1989.00021962008100020010x
Hall, M. B. (2000). Neutral Detergent-Soluble Carbohydrates a Laboratory Manual. Gainesville, FL: Institute of Food and Agricultural Science, University of Florida.

Hall, M. B., and Herejk, C. (2001). Differences in yields of microbial crude protein from in vitro fermentation of carbohydrates. J. Dairy Sci. 84, 2486-2493. doi: 10.3168/jds.S0022-0302(01)74699-1

Hall, M. B., Hoover, W. H., Jennings, J. P., and Webster, T. K. (1999). A method for partitioning neutral detergent-soluble carbohydrates. J. Sci. Food Agric. 79, 2079-2086. doi: 10.1002/(SICI)1097-0010(199912)79:15<2079:: AID-JSFA502>3.0.CO;2-Z

Hall, M. B., Pell, A. N., and Chase, L. E. (1998). Characteristics of neutral detergentsoluble fiber fermentation by mixed ruminal microbes. Anim. Feed Sci. Technol. 70, 23-39. doi: 10.1016/S0377-8401(97)00068-0

Hatfield, R., McCaslin, M., Miller, D., and Moutray, J. (2006). High Pectin Alfalfa. U.S. Patent Application 11/409,227, filed December 14, 2006. Alexandria, VA.

Hatfield, R. D., Ralph, J., and Grabber, J. H. (1999). Cell wall structural foundations: molecular basis for improving forage digestibilities. Crop Sci. 39, 27-37. doi: 10.2135/cropsci1999.0011183X003900010005x

Hatfield, R. D., and Weimer, P. J. (1995). Degradation characteristics of isolated and in situ cell wall lucerne pectic polysaccharides by mixed ruminal microbes. J. Sci. Food Agric. 69, 185-196. doi: 10.1002/jsfa.2740690208

Haynes, R. J., and Williams, P. H. (1993). Nutrient cycling and soil fertility in the grazed pasture ecosystem. Adv. Agron. 49:119-199. doi: 10.1016/S0065-2113(08)60794-4

Heldt, J. S., Cochran, R. C., Stokka, G. L., Farmer, C. G., Mathis, C. P., Titgemeyer, E. C., et al. (1999). Effects of different supplemental sugars and starch fed in combination with degradable intake protein on low-quality forage use by beef steers. J. Anim. Sci. 77, 2793-2802. doi: 10.2527/1999.77102793x

Hindrichsen, I. K., Wettstein, H. R., Machmüller, A., Jörg, B., and Kreuzer, M. (2005). Effect of the carbohydrate composition of feed concentratates on methane emission from dairy cows and their slurry. Environ. Monit. Assess. 107, 329-350. doi: 10.1007/s10661-005-3008-3

Huhtanen, P. (1988). The effects of barley, unmolassed sugar-beet pulp and molasses supplements on organic matter, nitrogen and fibre digestion in the rumen of cattle given a silage diet. Anim. Feed Sci. Technol. 20, 259-278. doi: 10.1016/0377-8401(88)90001-6

Jacobs, J. L., Hill, J., and Jenkin, T. (2009). Effect of different grazing strategies on dry matter yields and nutritive characteristics of whole crop cereals. Anim. Product. Sci. 49, 608-618. doi: 10.1071/EA08245

Jung, H. G. (1989). Forage lignins and their effects on fiber digestibility. Agron. J. 81, 33-38. doi: 10.2134/agronj1989.00021962008100010006x

Kalu, B. A., and Fick, G. W. (1981). Quantifying morphological development of alfalfa for studies of herbage quality 1. Crop Sci. 21, 267-271. doi: 10.2135/cropsci1981.0011183X002100020016x

Keles, G., Ates, S., Coskun, B., and Koc, S. (2013). "Re-growth yield and nutritive value of winter cereals," in Revitalising grasslands to sustain our communities: 22nd International Grassland Congress, 15-19 September, 2013 (Sydney, NSW: New South Wales Department of Primary Industry), 951-953.

Kim, S. C., Adesogan, A. T., and Arthington, J. D. (2007). Optimizing nitrogen utilization in growing steers fed forage diets supplemented with dried citrus pulp. J. Anim. Sci. 85, 2548-2555. doi: 10.2527/jas.2007-0059

Knapp, J. R., Laur, G. L., Vadas, P. A., Weiss, W. P., and Tricarico, J. M. (2014). Invited review: enteric methane in dairy cattle production: quantifying the opportunities and impact of reducing emissions. J. Dairy Sci. 97, 3231-3261. doi: $10.3168 /$ jds.2013-7234

Küchenmeister, K., Küchenmeister, F., Kayser, M., Wrage-Mönnig, N., and Isselstein, J. (2013). Influence of drought stress on nutritive value of perennial forage legumes. Int. J. Plant Product. 7, 693-710. Available online at: https:// www.sid.ir/en/journal/ViewPaper.aspx?id=339865

Lagrange, S., Beauchemin, K. A., MacAdam, J., and Villalba, J. J. (2020). Grazing diverse combinations of tanniferous and non-tanniferous legumes: implications for beef cattle performance and environmental impact. Sci. Total Environ. 746:140788. doi: 10.1016/j.scitotenv.2020.140788

Lee, C., Feyereisen, G. W., Hristov, A. N., Dell, C. J., Kaye, J., and Beegle, D. (2014). Effects of dietary protein concentration on ammonia volatilization, nitrate leaching, and plant nitrogen uptake from dairy manure applied to lysimeters. $J$. Environ. Qual. 43, 398-408. doi: 10.2134/jeq2013.03.0083 
Lee, J. M., Donaghy, D. J., and Roche, J. R. (2008). Effect of defoliation severity on regrowth and nutritive value of perennial ryegrass dominant swards. Agron. J. 100, 308-314. doi: 10.2134/agronj2007.0099

Lee, M. A., Davis, A. P., Chagunda, M. G., and Manning, P. (2017). Forage quality declines with rising temperatures, with implications for livestock production and methane emissions. Biogeosciences 14, 1403-1417. doi: 10.5194/bg-14-1403-2017

Lee, M. R. F., Harris, L. J., Moorby, J. M., Humphreys, M. O., Theodorou, M. K., MacRae, J. C., et al. (2002). Rumen metabolism and nitrogen flow to the small intestine in steers offered Lolium perenne containing different levels of watersoluble carbohydrate. Anim. Sci. 74, 587-596. doi: 10.1017/S1357729800052747

Leip, A., Billen, G., Garnier, J., Grizzetti, B., Lassaletta, L., Reis, S., et al. (2015). Impacts of European livestock production: nitrogen, sulphur, phosphorus and greenhouse gas emissions, land-use, water eutrophication and biodiversity. Environ. Res. Lett. 10:115004. doi: 10.1088/1748-9326/10/11/115004997

Leiva, E., Hall, M. B., and Van Horn, H. H. (2000). Performance of dairy cattle fed citrus pulp or corn products as sources of neutral detergent-soluble carbohydrates. J. Dairy Sci. 83, 2866-2875. doi: $10.3168 /$ jds.S0022-0302(00)75187-3

Liu, Y., Wu, Q., Ge, G., Han, G., and Jia, Y. (2018). Influence of drought stress on afalfa yields and nutritional composition. BMC Plant Biol. 18:13. doi: 10.1186/s12870-017-1226-9

Lobley, G. E., and Milano, G. D. (1997). Regulation of hepatic nitrogen metabolism in ruminants. Proc. Nutr. Soc. 56, 547-563. doi: 10.1079/PNS19970057

MacAdam, J., and Yost, M. (2020). Mountain hay. Progressive Forage. Available online at: https://www.progressiveforage.com/forage-types/alfalfa/mountainhay (accessed January 31, 2020).

MacAdam, J. W. (2019). "The elevated carbohydrate concentrations of high altitude-grown perennial legume forages," in Annual Meetings Abstracts. ASA, CSSA, and SSSA. Madison, WI. Available online at: https://scisoc.confex.com/ scisoc/2019am/meetingapp.cgi/Paper/119690 (accessed February 27, 2021).

MacAdam, J. W. (2020). "Development and nutritive value of high altitude-grown alfalfa and meadow bromegrass," in Annual Meetings Abstracts. ASA, CSSA, and SSSA. Madison, WI.

MacAdam, J. W., and Nelson, C. J. (2017). "Physiology of forage plants," in Forages, Vol. 1: An Introduction to Grassland Agriculture, 7th Edn, eds M. Collins, C. J. Nelson, K. J. Moore, and R. F. Barnes (Hoboken, NJ: Wiley Blackwell), 51-70.

MacAdam, J. W., and Villalba, J. J. (2015). Beneficial effects of temperate forage legumes that contain condensed tannins. Agriculture 20, 475-491. doi: 10.3390/agriculture5030475

Martin, N. P., Mertens, D. R., and Weimer, P. J. (2004). "Alfalfa: Hay, Haylage, Baleage and other novel products," in Proceedings of the Idaho Alfalfa and Forage Conference, February, 24-25, 2004 (Twin Falls, ID), 9-18.

Matthew, C., Hernandez-Garay, A., and Hodgson, J. (1996). Making sense of the link between tiller density and pasture production. Proce. New Zealand Grassland Assoc. 57, 83-87. doi: 10.33584/jnzg.1995. 57.2190

Miller, L. A., Moorby, J. M., Davies, D. R., Humphreys, M. O., Scollan, N. D., MacRae, J. C., et al. (2001). Increased concentration of water-soluble carbohydrate in perennial ryegrass (Lolium perenne L.): milk production from late-lactation dairy cows. Grass Forage Sci. 56, 383-394. doi: 10.1046/j.1365-2494.2001.0 0288.x

Miron, J., Yosef, E., Ben-Ghedalia, D., Chase, L. E., Bauman, D. E., and Solomon, R. (2002). Digestibility by dairy cows of monosaccharide constituents in total mixed rations containing citrus pulp. J. Dairy Sci. 85, 89-94. doi: 10.3168/jds.S0022-0302(02)74056-3

Moorby, J. M., Evans, R. T., Scollan, N. D., Mac Rae, J. C., and Theodorou, M. K. (2006). Increased concentration of water-soluble carbohydrate in perennial ryegrass (Lolium perenne L.). evaluation in dairy cows in early lactation. Grass Forage Sci. 61, 52-59. doi: 10.1111/j.1365-2494.2006.00507.x

Morgan, J. M. (1984). Osmoregulation and water stress in higher plants. Annu. Rev. Plant Physiol. 35, 299-319. doi: 10.1146/annurev.pp.35.060184.0 01503

Münnich, M., Klevenhusen, F., and Zebeli, Q. (2018). Feeding of molassed sugar beet pulp instead of maize enhances net food production of high-producing Simmental cows without impairing metabolic health. Anim. Feed Sci. Technol. 241, 75-83. doi: 10.1016/j.anifeedsci.2018.04.018
Nakayama, N., Saneoka, H., Moghaieb, R. E. A., Premachandra, G. S., and Fujita, K. (2007). Response of growth, photosynthetic gas exchange, translocation of 13C-labelled photosynthate and $\mathrm{N}$ accumulation in two soybean (Glycine max L. Merrill) cultivars to drought stress. Int. J. Agric. Biol. 9, 669-674.

Nocek, J. E. (1988). In situ and other methods to estimate ruminal protein and energy digestibility: a review. J. Dairy Sci. 71, 2051-2069. doi: 10.3168/jds.S0022-0302(88)79781-7

Old, C. A., Rossow, H. A., Lean, I. J., and Famula, T. R. (2018). Energetic efficiency and the first law: zthe California net energy system revisited. J. Anim. Sci. 96, 4882-4901. doi: 10.1093/jas/sky322

Orr, R. J., Rutter, S. M., Penning, P. D., and Rook, A. J. (2001). Matching grass supply to grazing patterns for dairy cows. Grass Forage Sci. 56, 352-361. doi: 10.1046/j.1365-2494.2001.00284.x

Owens, D., McGee, M., Boland, T., and O'Kiely, P. (2008). Intake, rumen fermentation and nutrient flow to the omasum in beef cattle fed grass silage fortified with sucrose and/or supplemented with concentrate. Anim. Feed Sci. Technol. 144, 23-43. doi: 10.1016/j.anifeedsci.2007.09.032

Owens, F. N., Qi, S., and Sapienza, D. A. (2014). Invited review: applied protein nutrition of ruminants-current status and future directions. Profes. Anim. Sci. 30, 150-179. doi: 10.15232/S1080-7446(15)30102-9

Owens, V. N., Albrecht, K. A., and Muck, R. E. (2002). Protein degradation and fermentation characteristics of unwilted red clover and alfalfa silage harvested at various times during the day. Grass Forage Sci. 57, 329-341. doi: 10.1046/j.1365-2494.2002.00333.x

Owens, V. N., Albrecht, K. A., Muck, R. E., and Duke, S. H. (1999). Protein degradation and fermentation characteristics of red clover and alfalfa silage harvested with varying levels of total nonstructural carbohydrates. Crop Sci. 39, 1873-1880. doi: 10.2135/cropsci1999.3961873x

Pelletier, S., Tremblay, G. F., Bélanger, G., Bertrand, A., Castonguay, Y., Pageau, D., et al. (2010). Forage nonstructural carbohydrates and nutritive value as affected by time of cutting and species. Agron. J. 102, 1388-1398. doi: 10.2134/agronj2010.0158

Peterson, P. R., Sheaffer, C. C., and Hall, M. H. (1992). Drought effects on perennial forage legume yield and quality. Agron. J. 84, 774-779. doi: 10.2134/agronj1992.00021962008400050003x

Pinzon, F. J., and Wing, J. M. (1976). Effects of citrus pulp in high urea rations for steers. J. Dairy Sci. 59, 1100-1103. doi: 10.3168/jds.S0022-0302(76)84328-7

Putnam, D., DeBen, C., Chavez, B., and Orloff, S. (2017). Experiments With Reduced Lignin Alfalfa. U.C. Davis Field Day, 11 May 2017. Retrieved from: http://agric.ucdavis.edu/files/262598.pdf (accessed February 27, 2021).

Ramos-Aviña, D., Plascencia, A., and Zinn, R. (2018). Influence of dietary nonstructural carbohydrate concentration on growth performance and carcass characteristics of Holstein steers. Asian-australas. J. Anim. Sci. 31:859. doi: 10.5713/ajas.17.0425

Reddy, T. Y., Reddy, V. R., and Anbumozhi, V. (2003). Physiological responses of groundnut (Arachis hypogaea L.) to drought stress and its amelioration: a review. Acta Agron. Hungarica. 51, 205-227. doi: 10.1556/AAgr.51.2003.2.9

Rigby, H., Clarke, B. O., Pritchard, D. L., Meehan, B., Beshah, F., Smith, S. R., et al. (2016). A critical review of nitrogen mineralization in biosolidsamended soil, the associated fertilizer value for crop production and potential for emissions to the environment. Sci. Total Environ. 541, 1310-1338. doi: 10.1016/j.scitotenv.2015.08.089

Rosendo, O., Hall, M. B., Staples, C. R., and Bates, D. B. (1999). Effects of polysaccharides on fiber digestion kinetics and microbial protein production in vitro. J. Dairy Sci. 82:89.

Satter, L. D., and Roffler, R. E. (1975). Nitrogen requirement and utilization in dairy cattle. J. Dairy Sci. 58, 1219-1237. doi: 10.3168/jds.S0022-0302(75)84698-4

Sharif, M., Ashraf, M. S., Mushtaq, N., Nawaz, H., Mustafa, M. I., Ahmad, F., et al. (2018). Influence of varying levels of dried citrus pulp on nutrient intake, growth performance and economic efficiency in lambs. J. Appl. Anim. Res. 46, 264-268. doi: 10.1080/09712119.2017.1294540

Smith, S. B., and Crouse, J. D. (1984). Relative contributions of acetate, lactate and glucose to lipogenesis in bovine intramuscular and subcutaneous adipose tissue. J. Nutrit. 4, 792-800. doi: 10.1093/jn/114.4.792

Smith, S. B., and Johnson, B. J. (2014). "Marbling: management of cattle to maximize the deposition of intramuscular adipose tissue," 2014 Beef Research White Paper on Product Quality. Centennial, CO: Cattlemen's Beef Board and National Cattlemen's Beef Association. 
Stewart, E. K., Beauchemin, K. A., Dai, X., MacAdam, J. W., Christensen, R. G., and Villalba, J. J. (2019). Effect of tannin-containing hays on enteric methane emissions and nitrogen partitioning in beef cattle. J. Anim. Sci. 97, 3286-3299. doi: $10.1093 /$ jas/skz206

Strobel, H. J., and Russell, J. B. (1986). Effect of pH and energy spilling on bacterial protein synthesis by carbohydrate-limited cultures of mixed rumen bacteria. J. Dairy Sci. 69, 2941-2947. doi: 10.3168/jds.S0022-0302(86)80750-0

Tecle, I. Y., Viands, D. R., Hansen, J. L., and Pell, A. N. (2006). Response from selection for pectin concentration and indirect response in digestibility of alfalfa. Crop Sci. 46, 1081-1087. doi: 10.2135/cropsci2005.05-0087

Titgemeyer, E. C., Bourquin, L. D., and Fahey, J.r., G.C. (1992). Disappearance of cell wall monomeric components from fractions chemically isolated from alfalfa leaves and stems following in situ ruminal digestion. J. Sci. Food Agric. 58, 451-463. doi: 10.1002/jsfa.2740580402

Totty, V. K., Greenwood, S. L., Bryant, R. H., and Edwards, G. R. (2013). Nitrogen partitioning and milk production of dairy cows grazing simple and diverse pastures. J. Dairy Sci. 96, 141-149. doi: 10.3168/jds.2012-5504

Turner, L. R., Donaghy, D. J., Lane, P. A., and Rawnsley, R. P. (2006). Effect of defoliation management, based on leaf stage, on perennial ryegrass (Lolium perenne L.), prairie grass (Bromus willdenowii Kunth.) and cocksfoot (Dactylis glomerata L.) under dryland conditions. 2. nutritive value. Grass Forage Sci. 61, 175-181. doi: 10.1111/j.1365-2494.2006.00524.x

Van Soest, P. J. (1967). Development of a comprehensive system of feed analyses and its application to forages. J. Anim. Sci. 26, 119-128. doi: $10.2527 /$ jas $1967.261119 \mathrm{x}$

Van Soest, P. J. (1994). Nutritional Ecology of the Ruminant. Ithaca, NY: Cornell University Press. doi: 10.7591/9781501732355

Varga, G. A., and Hoover, W. H. (1983). Rate and extent of neutral detergent fiber degradation of feedstuffs in situ. J. Dairy Sci. 66, 2109-2115. doi: 10.3168/jds.S0022-0302(83)82057-8

Veits, M., Khait, I., Obolski, U., Zinger, E., Boonman, A., Goldshtein, A., et al. (2019). Flowers respond to pollinator sound within minutes by increasing nectar sugar concentration. Ecol. Lett. 22, 1483-1492. doi: 10.1111/el e.13331

Villarreal, M., Cochran, R. C., Rojas-Bourrillón, A., Murillo, O., Muñoz, H., and Poore, M. (2006). Effect of supplementation with pelleted citrus pulp on digestibility and intake in beef cattle fed a tropical grassbased diet (Cynodon nlemfuensis). Anim. Feed Sci. Technol. 125, 163-173. doi: 10.1016/j.anifeedsci.2005.05.020

Weimer, P. J. (1992). Cellulose degradation by ruminal microorganisms. Crit. Rev. Biotechnol. 12, 189-223. doi: 10.3109/0738855920 9069192

Wilkinson, T. J., Ur, J., and Casana, J. (2004). "From nucleation to dispersal: trends in settlement pattern in the northern fertile crescent," Side-by-Side Survey: Comparative Regional Studies in the Mediterranean World, eds J. Cherry and S. Alcock (Oxford: Oxbow Books), 189-205.

Wilson, J. R. (1982). "Environmental and nutritional factors affecting herbage quality," in Nutritional Limits to Animal Production from Pastures conference: Proceedings of an International Symposium held at St. Lucia, Queensland, Australia, August 24th-28th, 1981, ed J. B. Hacker (Farnham Royal: CAB), 111-113.
Wilson, J. R. (1983a). "Effects of water stress on herbage quality," in Proc. 14th Int Grassl. Congr, eds J. A. Smith and V. W. Hays (Lexington, KY; Boulder, CO: Westview Press), 470-474.

Wilson, J. R. (1983b). Effects of water stress on in vitro digestibility and chemical composition of herbage of tropical pasture species. Aust. J. Agric. Res. 34, 337-390. doi: 10.1071/AR9830377

Wilson, J. R., Deinum, B., and Engels, F. M. (1991). Temperature effects on anatomy and digestibility of leaf and stem of tropical and temperate forage species. NJAS Wageningen J. Life Sci. 39, 31-48. doi: 10.18174/njas.v39i1.16551

Wilson, J. R., and Minson, D. J. (1983). Influence of temperature on the digestibility of the tropical legume Macroptilium atropurpureum. Grass Forage Sci. 38, 39-44. doi: 10.1111/j.1365-2494.1983.tb01620.x

Wilson, J. R., and Ng, T. T. (1975). Influences of water stress on parameters associated with herbage quality of Panicum maximum var. trichoglume. Austr. J. Agric. Res. 26, 127-136. doi: 10.1071/AR9750127

Wilson, R. L., Bionaz, M., MacAdam, J. W., Beauchemin, K. A., Naumann, H. D., and Ates, S. (2020). Milk production, nitrogen utilization, and methane emissions of dairy cows grazing grass, forb, and legume-based pastures. J. Anim. Sci. 98:p.skaa220. doi: 10.1093/jas/skaa220

$\mathrm{Xu}$, Q., and Huang, B. (2000). Effects of differential air and soil temperature on carbohydrate metabolism in creeping bentgrass. Crop Sci. 40, 1368-1374. doi: $10.2135 /$ cropsci2000.4051368x

Yari, M., Valizadeh, R., Naserian, A. A., Jonker, A., Azarfar, A., and Yu, P. (2014). Effects of including alfalfa hay cut in the afternoon or morning at three stages of maturity in high concentrate rations on dairy cows performance, diet digestibility and feeding behavior. Anim. Feed Sci. Technol. 192, 62-72. doi: 10.1016/j.anifeedsci.2014.04.001

Yu, P., Christensen, D. A., McKinnon, J. J., and Markert, J. D. (2003). Effect of variety and maturity stage on chemical composition, carbohydrate and protein subfractions, in vitro rumen degradability and energy values of timothy and alfalfa. Can. J. Anim. Sci. 83, 279-290. doi: 10.4141/A02-053

Zeder, M. A., and Hesse, B. (2000). The initial domestication of goats (Capra hircus) in the Zagros Mountains 10,000 years ago. Science 287, 2254-2257. doi: 10.1126/science.287.5461.2254

Zhao, X. H., Liu, C. J., Li, C. Y., and Yao, J. H. (2013). Effects of neutral detergent soluble fiber and sucrose supplementation on ruminal fermentation, microbial synthesis, and populations of ruminal cellulolytic bacteria using the rumen simulation technique (RUSITEC). J. Integr. Agric. 12, 1471-1480. doi: 10.1016/S2095-3119(13)60743-1

Conflict of Interest: The authors declare that the research was conducted in the absence of any commercial or financial relationships that could be construed as a potential conflict of interest.

Copyright (c) 2021 Villalba, Ates and MacAdam. This is an open-access article distributed under the terms of the Creative Commons Attribution License (CC BY). The use, distribution or reproduction in other forums is permitted, provided the original author(s) and the copyright owner(s) are credited and that the original publication in this journal is cited, in accordance with accepted academic practice. No use, distribution or reproduction is permitted which does not comply with these terms. 